\section{Immunoglobulin $\mathrm{A}$ and $\mathrm{C}$ reactive protein levels in ankylosing spondylitis}

SIR, We read with interest the recent paper by Sanders et al on the correlation of immunoglobulin and $\mathrm{C}$ reactive protein (CRP) levels in 22 patients with ankylosing spondylitis (AS) and 20 patients with rheumatoid arthritis (RA). ${ }^{1}$ The authors found that IgA serum levels, though raised in AS, do not correlate with CRP levels as they do in $\mathrm{RA}$, suggesting that the mechanism of increase of $\operatorname{IgA}$ in the two diseases may be different. They conclude that production of $\operatorname{IgA}$ in AS is unrelated to the stimulation of acute phase reactants, reflecting a specific mucosal immune stimulation, possibly in the gut. Thus IgA may be a marker of the pathogenesis of AS.

We measured immunoglobulin levels (IgA, IgG, IgM) by radial immunodiffusion and CRP levels by nephelometry in 67 patients (59 male, eight female) with definite AS (New York criteria). The age range was 17-64 years, mean age 42 years. Our results differed from those of Sanders et al (Table 1). The mean serum IgA level in patients with a raised CRP $(>1.5 \mathrm{mg} / \mathrm{l})$ was higher than the mean serum IgA level in patients with CRP $<1.5 \mathrm{mg} / \mathrm{l}$. This difference was significant $(p=0 \cdot 03)$. Although a positive correlation between $\operatorname{IgA}$ and IgG serum levels was found $(p=0 \cdot 03$, Spearman's test $)$ only $\operatorname{IgA}$ showed a significant positive correlation with CRP levels $(p=0) \cdot 05$, Spearman's test). No correlation between IgG or IgM and CRP levels was found.

The discordance between our results and those of Sanders et al could be related to the different number of patients included in the survey. To our knowledge, two other groups of researchers have studied the correlation between IgA and CRP levels. Our findings are in accordance with those of Cowling and Trull, ${ }^{2-4}$ who showed a positive correlation between IgA and CRP levels. Laurent and Panayi have reported an increase of $\operatorname{IgA}$ serum levels in patients with high values of CRP, but no absolute correlation was found ${ }^{5}$; these data, however, were not shown in their report.
Assessment of clinical activity is difficult in AS, particularly when there is only axial involvement. ${ }^{6}$ Recently it was reported that CRP is better than erythrocyte sedimentation rate as an indicator of disease activity. ${ }^{7}$ In longitudinal studies (in which CRP was not measured) $\operatorname{IgA}$ was found to be a useful tool in the assessment of disease activity in patients with AS. ${ }^{89}$ Our results are in accordance with these findings since in our patients CRP correlated with IgA but not with IgG or IgM.

IgA is the most important immunoglobulin secreted from mucosal sites. If the mucosal antigenic stimulation acts as a trigger of phases of active inflammatory disease in $\mathrm{AS}^{10}$ then $\operatorname{IgA}$ levels should correlate better than other immunoglobulins with clinical activity or acute phase reactants such as CRP, as occurred in our patients. We think that these observations and not those reported by Sanders et al are compatible with the concept of an antigenic mucosal stimulation in the pathogenesis of AS.

Departments of Rheumatology and

A COLLADO

*Immunology,

Hospital Clinico y Provincial,

Barcelona, Spain

R SANMARTI

M A BRANCÓS

E KANTEREWICZ

T GALLART*

J ROTÉS-QUEROL

Department of Statistics,

A $\operatorname{coBOS}$

University of Barcelona,

Spain

\section{References}

1 Sanders K M, Hertzman A. Escobar M R, Littman B H. Correlation of immunoglobulin and $C$ reactive protein levels in ankylosing spondylitis and rheumatoid arthritis. Ann Rheum Dis 1987; 46: 273-6.

2 Cowling P. Ebringer R. Ebringer A. Association of inflammation with raised serum $\lg \mathrm{A}$ in ankylosing spondylitis. $A n n$ Rheum Dis 1980: 39: 545-9.

3 Trull A K. Ebringer R. Panayi G S, Colthorpe D. James D C O. Ebringer A. IgA antibodies to Klebsiella pneumoniae in ankylosing spondylitis. Scand J Rheumatol 1983; 12: 249-53.

4 Trull A. Ebringer A. Panayi G. Ebringer R, James D C O. HLA-B27 and the immune response to enterobacterial antigens in ankylosing spondylitis. Clin Exp Immunol 1984: 55: 74-80.

5 Laurent M R. Panayi G S. Acute phase proteins and serum

Table 1 CRP and immunoglobulin levels of patients with AS

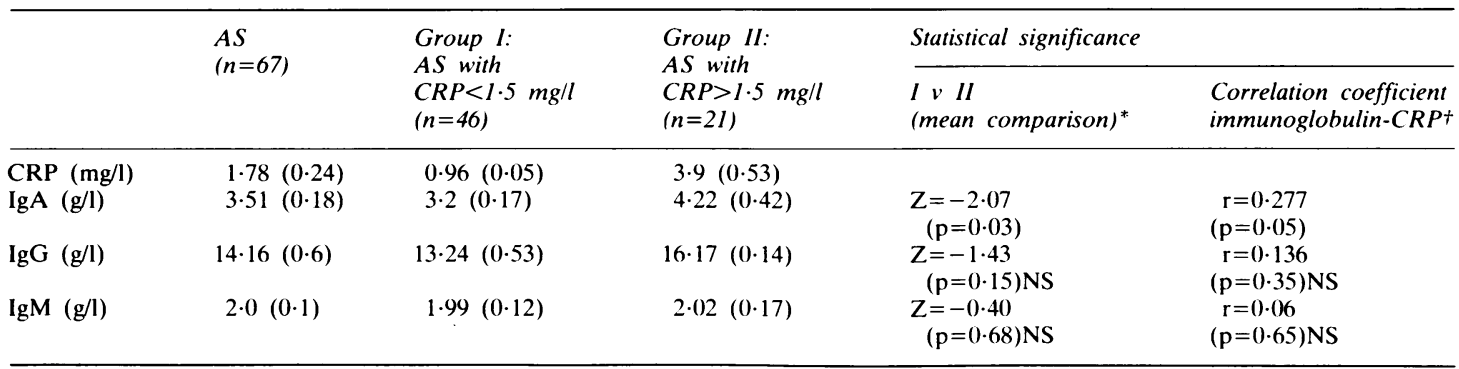

* Mean correlation by Mann-Whitney $U$ test

† Spearman's correlation coefficient (measured in 48 patients with CRP $>0 \cdot 6 \mathrm{mg} / \mathrm{l}$ minimal level detected by nephelometry). 
immunoglobulins in ankylosing spondylitis. Ann Rheum Dis 1983; 42: 524-8.

6 Scott D G I, Ring E F J, Bacon P A. Problems in the assessment of disease activity in ankylosing spondylitis. Rheumatol Rehabil 1981; 42: 524-8.

7 Nashel D J, Petrone D L, Ulmer C C. Sliwinski A J. C-reactive protein: a marker for disease activity in ankylosing spondylitis and Reiter's syndrome. J Rheumatol 1986; 13: 364-7.

8 Franssen M J A M, Van de Putte L B A, Gribnau F W J. IgA serum levels and disease activity in ankylosing spondylitis: a prospective study. Ann Rheum Dis 1985; 44: 766-71.

9 Dougados M, Gaudouen Y, Blan M, Boumier P, Raichvarg D, Amor B. Vitesse de sedimentation globulaire et immunoglobulines sériques au cours de la pelvispondylite rhumatismale. Rev Rhum Mal Osteoartic 1987; 54: 273-8.

10 Ebringer $\mathrm{R} \mathrm{W}$, Cawdell D R. Cowling P, Ebringer A. Sequential studies in ankylosing spondylitis: association of Klebsiella pneumoniae with active disease. Ann Rheum Dis 1978; 37: 146-51.

\section{Book review}

Back Pain: Methods for Clinical Investigation and Assessment. Eds D W L Hukins, R C Mulholland. Pp. 158. £25.00. Manchester University Press: Manchester. 1986.

I am sure it speaks a lot for this book that I had already purchased a copy before being sent one to review. The book is a synopsis of a meeting held by the Society for Back Pain Research in 1986 and has resulted in an up to date account of the status of the various methods available for investigating back pain. The book starts with a detailed account of the important epidemiological study on the prevalence of back pain commissioned by the Consumers Association and already quoted in Which (Fairbank). The importance of lumbar mobility (Burton), the use of microcomputers as an aid in the clinic (Gardner), and the value of Dynamic Moire topography as a non-invasive method of assessing leg length equality (Daunt) in patients with backache are some of the subjects dealt with in a very readable and well illustrated text.

The main bulk of the book is devoted to investigative techniques, including ultrasound, thermography, and computed tomography, but with the main emphasis on magnetic resonance imaging (MRI). Four papers with excellent illustrations bring the reader the most up to date information on MRI as well as a full, if at times complicated, chapter on quantitative magnetic resonance, with details and illustrations on determining the water content of the disc, which promises to be an interesting area of back pain research.

Finally, the balance between anatomy and physiology is restored by two papers clearly illustrating the value of electrophysiological studies (electromyography and somosensory evoked potential) in the diagnosis of root lesion.
Inevitably in a book that has been produced so promptly, there are some publishing errors, with occasional spelling mistakes, and in chapter 14 I noted the legends to two figures were tranposed.

I would strongly recommend this book to anyone with an $\stackrel{?}{?}$ interest in backache as it will bring them right up to date with current concepts of the investigation of back pain. I흐 also understand that further similar books are to follow, $\bar{D}$ dealing with the management of back pain. If they $\mathbb{D}$ maintain this standard I shall be buying them too.

Consultant in Rheumatology

J R JENNER and Rehabilitation

Notes

\section{Inaugural Pan-Pacific Connective Tissue Conference}

A combined meeting of the Australian and New Zealand, Japanese, and West Coast American Connective Societies will be held at the Ramada Reef Resort, Cairns, Northern? Queensland, Australia, on 5-9 November 1989. The theme will be "cellular influences on matrix structure and furece- $\overrightarrow{0}$ tion'. Further details from Peter Ghosh, Raymond Pur\&s $\infty$ Research Laboratories, (The University of Sydney), THe. Royal North Shore Hospital of Sydney, St Leonards, N 2065, Australia.

Euromedicine 1987: Rheumatoid arthritis-actual aspects and future trends

This meeting will be held in Montpellier, France, on $1 \frac{0}{P}$. November 1987. There will be simultaneous FrenchEnglish translation. No registration fee required. Furthep information from Professor Jacques Sany, Alice Congrès Parc du Millénaire, Route de Mauguio, 34036 Montpellie? CEDEX.

\section{British Cervical Spine Society}

The annual meeting of the British Cervical Spine Societyn will take place on 6 and 7 November 1987 in the RoberP Jones and Agnes Hunt Orthopaedic Hospital, Oswestry N Topics will include 'Surgery for cervical spondylosis?' and 'The rheumatoid neck'. Further details from Mr Alan Crockard FRCS, The National Hospitals for Nervous Diseases, Maida Vale, London W9 1TL. 